\title{
Container Ship Accident Analysis due to Container Stacked on Deck as an Attempt to Improve Maritime Logistic System
}

\author{
Gafero Priapalla Rahim and Sunaryo* \\ Department of Mechanical Engineering, Universitas Indonesia. Kampus UI Depok 16424 Indonesia
}

\begin{abstract}
This paper analyses factors that might cause accidents to the container ships due to containers stacked on deck, and propose applicable actions to minimize these factors. The number, capacity, and speed of hatch-coverless container ships worldwide have increased significantly since the latest decade due to the increase of world trade. There is also a trend of stacking more containers on deck in order to increase the capacity of the ships. This phenomenon makes the number of container ship accidents also increasing; particularly capsize or sink. Even though merchant ships have to comply with safety rules and regulations, but the number of accidents still significantly high. The accidents usually cause great loses to the cargo and damage the overall logistic system. The sources of container ship accidents can be categorized into the ship itself, the environment, human factor, and management. In this study, accidents data and related information were gathered through literature study, on the spot observation, and direct interviews with relevant parties. Causes of accidents were then identified using cause and effect analysis. Based on the findings from the analysis, options for overcoming them were simulated to obtain the most applicable solutions that would minimize the accidents.
\end{abstract}

Keywords: Cargo, fishbone analysis, lashing, safety, shipping

\section{Introduction}

Indonesia is the largest archipelago in the world, comprising more than 17000 islands, with the second longest coastline after Canada and vast ocean of nearly $6 \times 10^{6} \mathrm{~km}^{2}$ which includes the archipelagic waters, territorial sea and exclusive economic zone [1]. Indonesia makes the sea access links between the islands. For Indonesia as a maritime country, the export-import of goods through the sea is very important to promote the country's economy. Most of the cargo shipping is using containers due to international practices and their many benefits. Following the trend of containerization, so as the container ships are also developing in size; capacity; and stowage system.

The hallmark of the container ship is standardized so that the optimal placement of containers could be arranged [2]. According to data published by the United Nations Conference on Trade And Development [3], the carrying amount of the active container

\footnotetext{
* Corresponding author: naryo@eng.ui.ac.id
} 
ships that sail around the world in 2016, approximately 6086 vessels. The container ship has become common too in Indonesia, as especially in conjunction with the government's policy in implementing "Sea Highway" program. It shows that the container vessel has an important role in the world's logistic system.

However, in line with the presence of many container ships, there are also many accidents occurred to container ships. According to the data recorded by the European Maritime Safety Agency [4], there were 1101 cases of container ship accidents worldwide in the range of 2011 to 2015 . These accidents usually occur due to natural factors, incorrect stowage plan, overloaded containers, bad lashing system, hatch cover condition, the placement of dangerous goods containers, unsafe plugging of reefer container, human error, etc.

In this study, data comes from several transport safety agencies in the form of an investigation report. These sources include The Transportation Safety Board of Canada (TSB), Marine Accident Investigation Branch UK (MAIB), and The Federal Bureau of Maritime Casualty Investigation Germany (BSU). From the data that has been collected, then data is sorted to get the accident data related to the container load on the deck. After that will be analyzed further by using fishbone analysis method, the focus of this research is to investigate the sources of an accident caused by containers that were stacked on the deck so that attempts to minimize them could be proposed.

\section{Methodology}

In this study, statistical data related to container ships accidents were collected from many sources worldwide, as a basis for supporting the significance of the study. Only data related to accidents occurred due containers stacked on deck were used in the analyses. "Fishbone" cause and effect diagram analysis was carried out to investigate the core sources of the accidents [5], and based on the results of the analyses solutions were proposed to minimize the accident from its roots.

According to data from the European Maritime Safety Agency, from 2011 to 2015 there was 6403 cargo ship involved in 5942 cases of ship accidents, the number was increasing every year. For container ships, there are more than 1101 cases in the period of 2011 to 2015. Distribution of the number of accidents every year and the type of ship involved is presented in Figure 1.

From 4956 of specific cases, the most commonly occurring cases or around $25 \%$ of total cases were due to factors that were happened in the engine room. In addition, for the cases that were due to crash on deck are about $10 \%$ of the total cases. They occurred on cargo hold $5 \%$ and freeboard deck $5 \%$. Although it has a small percentage, the cost of cargo lost and their effect on the environment is worth considering.

Based on the data published by the European Maritime Safety Agency in the range of 2011 to 2015, accidents that are often experienced by the container ship are collision; fire/explosion; grounding; and wear out equipment. There are more than 200 cases of collisions. Accidents happened to containers stored on deck are caused by reefer containers and dangerous goods containers due to wrong placement; leaks; and improper plugging.

Accidents as a result of wear out equipment include bad lashing system and corroded hatch cover. Lashing system on the container is very important for the safety of containers. The lashing system should be checked regularly and replaced when they have already not met the standards. Especially those are stored on decks, because they have the potential to fall due to the force from the wind and rolling of the ship. Furthermore, in the case of wear out hatch cover, even though this is rare, but may potentially lead to an accident. Similar to the lashing system, the hatch cover must always be checked for its strength and shape, to 
spare from cracking. The strength of a hatch cover determines the balance and safety of cargo containers is on deck.

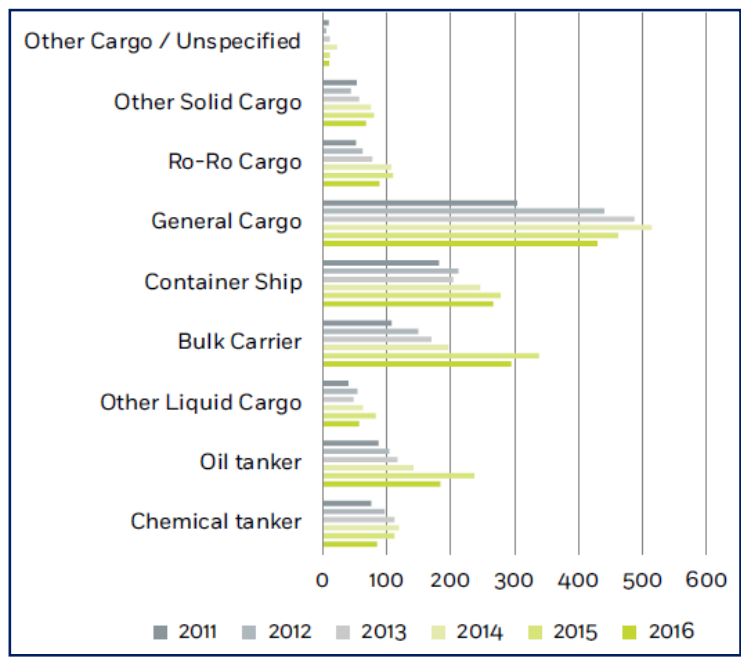

Fig. 1. Distribution of cargo ships involved

Besides data from EMSA (European Maritime Safety Agency), some data that related to container ship accident due to container stack on deck are:

\subsection{ATSB}

ATSB or Australian Transport Safety Bureau is an Australian bureau that having a specific duty to transportation accident in Australia [6]. The data by ATSB are container ship accidents data from 1982 to 2010.

Table 1. Container ship accident data due to container on deck by ATSB from 1982 to 2010.

\begin{tabular}{cccc}
\hline No & Ship's name & Date & Type of accident \\
\hline 1 & Kota Pahlawan & 16 June 2006 & Cargo damage \\
2 & MSC Lugano & 31 March 2008 & Fire \\
3 & Pacific Adventurer & 11 March 2009 & Loss of cargo \\
4 & Maersk Duffield & 10 December 2009 & Fire \\
\hline
\end{tabular}

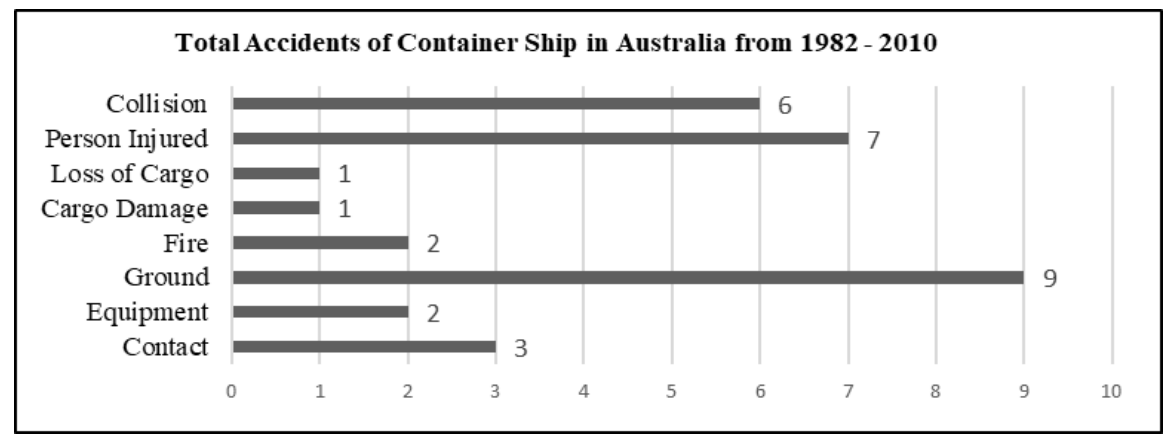

Fig. 2, Total accidents of container ship in Australia from 1982 to 2010 


\subsection{MAIB}

MAIB or Marine Accident Investigation Branch is an accident investigation agency at sea involving British ships all over the world as well as all ships located in British territorial waters [7]. The following data occurred during an accident from 1998 to 2015 presented in graphical form:

Table 2. Container ship accident data due to container on deck by MAIB from 1998 to 2015.

\begin{tabular}{cccc}
\hline No & Ship's name & Date & Type of accident \\
\hline 1 & Annabella & 26 February 2007 & Loss of cargo \\
2 & Dutch Navigator & 25 April 2001 & Cargo damage \\
3 & Maersk Doha & 2 October 2006 & Fire \\
4 & P\&O Nedlloyd Genoa & 27 January 2006 & Loss of cargo \\
\hline
\end{tabular}

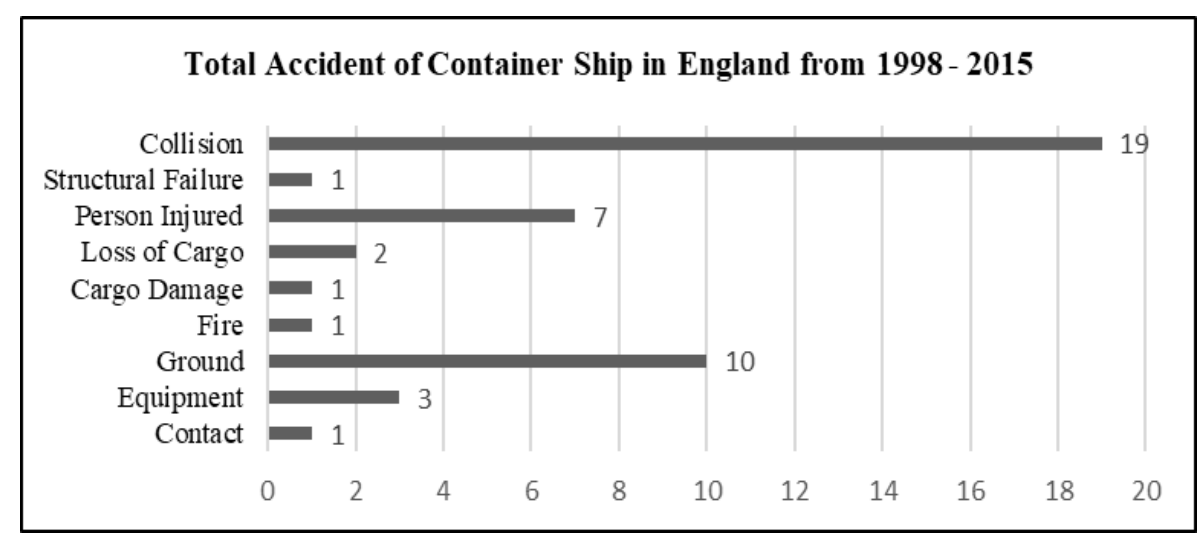

Fig. 3. Total accidents of container ship in England from 1998 to 2015

\subsection{BSU}

BSU (Bundesstelle fur Seeunfalluntersuchung) or can be called the "Federal Bureau of Maritime Casualty Investigation" is a sea-based accident investigation agency from Germany [8].

Table 3. Container ship accident data due to container on deck by BSU from 2002 to 2015.

\begin{tabular}{cccc}
\hline No & Ship's name & Date & Type of accident \\
\hline 1 & Punjab senator & 30 May 2005 & Fire \\
2 & CMV Yorkshire & 15 December 2005 & Loss of cargo \\
3 & Hanjin London & 10 July 2006 & Fire \\
4 & JRS Canis & 12 January 2007 & Loss of cargo \\
5 & Duncan Island & 06 November 2007 & Loss of cargo \\
7 & MSC Flaminia & 14 July 2012 & Fire \\
8 & Atlantic Cartier & 1 May 2013 & Fire \\
9 & Hanjin Athens & 6 May 2014 & Fire \\
10 & YM Uniformity & 18 May 2014 & Fire \\
11 & Thetis D & 26 October 2015 & Fire \\
12 & MSC Katrina & 20 November 2015 & Fire \\
\hline
\end{tabular}




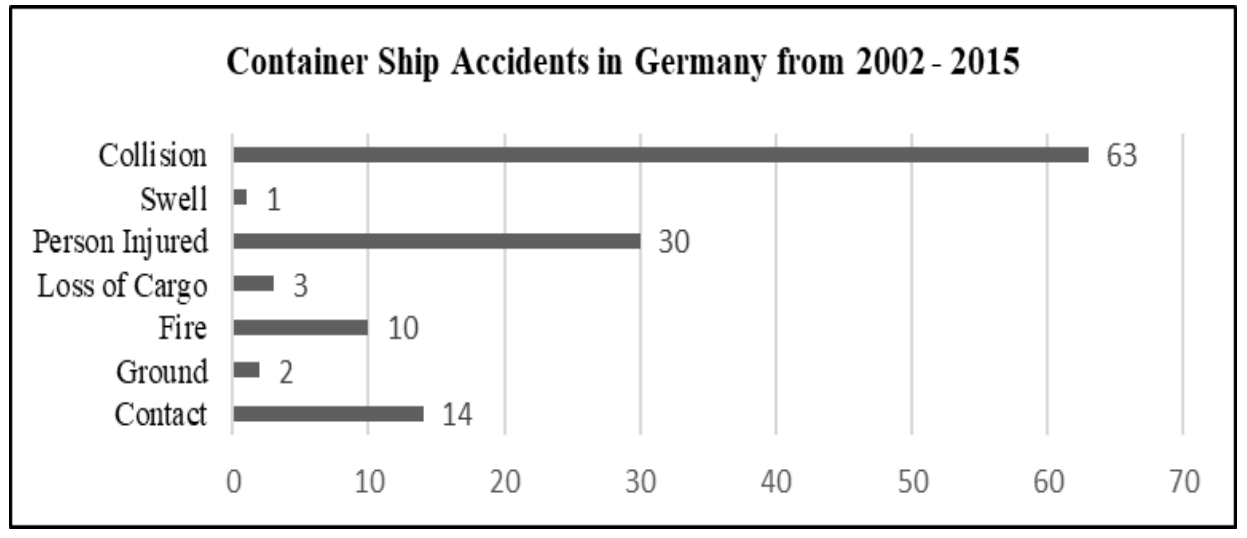

Fig. 4. Container ship accidents in Germany from 2002 to 2015

\subsection{TSB}

TSB or Transportation Safety Board is an independent institution owned by Canada [9]. TSB records data on transport accidents. The following are accident data on container vessels recorded by TSB from 1991 to 2015 :

Table 4. Container ship accident data due to container on deck by TSB from 1991 to 2015.

\begin{tabular}{cccc}
\hline No & Ship's Name & Year & Type of Accident \\
\hline 1 & Canada Senator & 1992 & Dangerous goods released \\
2 & Flottbek & 2005 & Cargo shift/cargo loss \\
3 & Nils B & 1998 & Explosion \\
4 & Nils B & 1998 & Fire \\
5 & Oocl Belgium & 1998 & Explosion \\
6 & Kent Explorer & 1986 & Fire \\
7 & Maersk Patras & & Fire \\
8 & Hyundai Republic & 2001 & Dangerous goods released \\
9 & Cielo di San Francisco & 1998 & Cargo shift/cargo loss \\
10 & Cap Blanche & 2006 & Fire \\
11 & Hanjin Seattle & 2011 & Cargo shift/cargo loss \\
\hline
\end{tabular}

\section{Result and discussion}

In order to identify the main sources of accidents occured to containers stacked on deck, cause and effect or "fish bone" analysis was used. The causes are classified into four categories, including: ship system, the environment, human factors, and management as shown in Figure 6. 


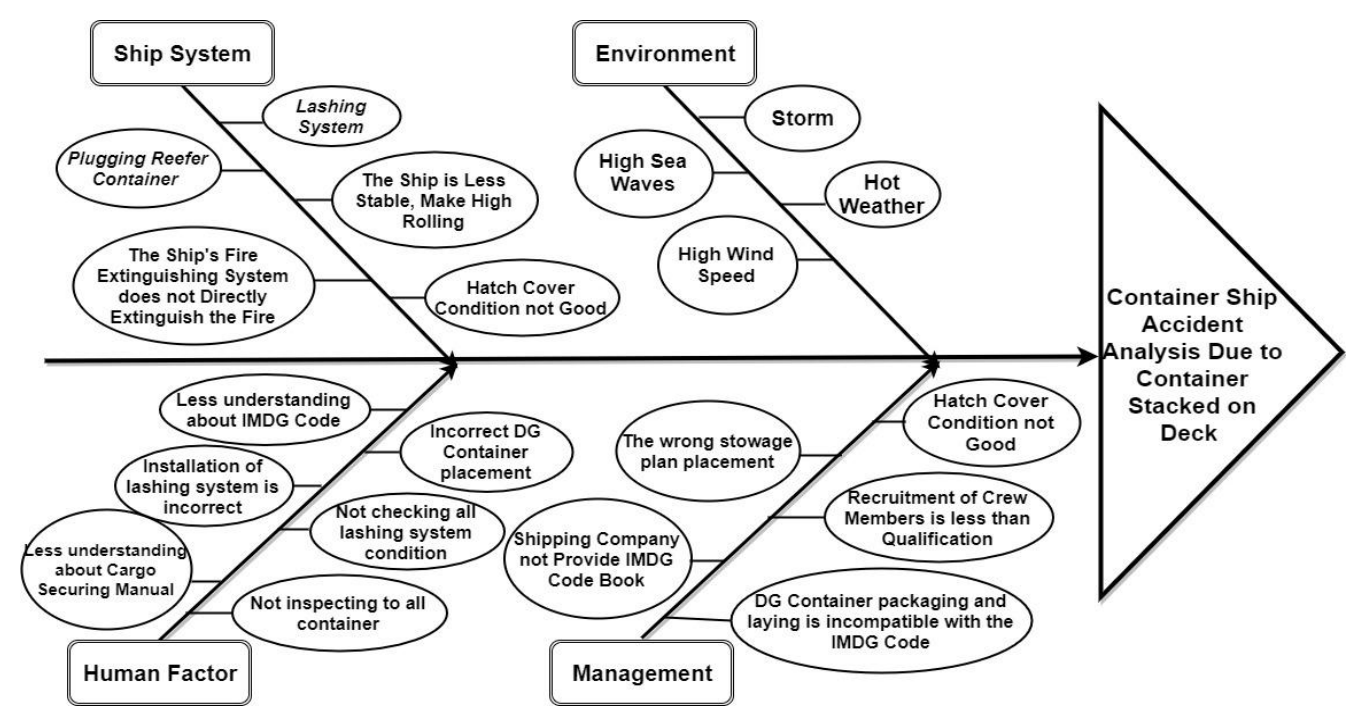

Fig. 6. Fish Bone Diagram Analysis

\subsection{Ship system analysis}

Some analysis of the ship system including the lashing system, plugging reefer container, the ship is less stable resulting in high rolling, ship extinguishing system that does not immediately extinguish the fire and hatch cover conditions are less good [10]. The lashing system is one of the important things in the safety of container load, especially the load on the deck [11]. In the case of the accidents described above, the shipwreck of the Pacific Adventurer, the Annabella ship, the P \& O Nedlloyd Genoa ship, the CMV Yorkshire ships, the JRS Canis ship, and the Duncan Island vessel are examples of accidents due to the inadequate lashing system used on board. The triggers of accidents on these vessels because it is not a strong lashing system, not a good use of lashing system is applied and the lack of maintenance lashing system.

Plugging for reefer containers can potentially cause sparks that can cause a fire on a ship. One example of the ship caused by plugging reefer container is the case of MSC Flaminia ship accident. Lack of surveillance, checking, and safeguarding of this reefer container plugging system are the factors that cause a fire. The stability of the vessel becomes fundamental to the safety of container vessels. Ships that have negative stability will make the ship easy to roll in the event of bad weather. Examples of accidents caused by the low stability of the ship are the case of the Passenger Adventurer's shipwreck and the $\mathrm{P} \& \mathrm{O}$ Nedlloyd Genoa ship.

A fire extinguisher in a ship becomes one of the causes of an accident. Although not the main cause, it can be an incident factor because if the fire system does not work immediately, it will cause a spark to become a fire. The last sub-cause factor is the poor hatch cover condition. The P \& O Nedlloyd Genoa ship is an accident caused by poor hatch cover conditions. This condition is caused because there is no check, care, and change of hatch cover periodically. If the hatch cover is not good (its construction is not strong), then the support force will be reduced container so that it can cause loss of cargo. 


\subsection{Environment analysis}

Some environmental factors that can cause shipwreck accidents due to cargo on the deck include storms, high sea waves, hot weather, and high wind speed. Hurricane weather backed by high sea waves and strong winds causes the ship to experience high rolling and can make a container load regardless of its pile. Conditions like this will make the ship experience loss of cargo. Examples of accidents caused by stormy weather, high ocean waves and high winds include the case of Pacific Passenger Adventurer crashes, Annabella ships, P \& O Nedlloyd Genoa ships, CMV Yorkshire ships, JRS Canis ships, and Duncan Island ships.

Hot weather will compromise container loads that are dangerous goods. This condition can cause cargo to cause a fire and trigger a fire. One example of accidents caused by the hot weather is a case of explosion on board the MSC Flaminia because it is caused by the dangerous goods load carried.

\subsection{Human factor analysis}

Human factors causing this type of accident include lack of understanding of the IMDG Code, putting inaccurate DG Container, incorrectly installed lashing system, not checking the condition of all lashing systems, lack of understanding of manual cargo and noninspection of containers. Understanding of the IMDG Code concerns the treatment of container loads that are dangerous goods. During a field study with the Tanjung Priok Syahbandar party, it was found that a chief officer did not understand the IMDG Code. Though the IMDG Code is very important, especially if there are dangerous goods that he brought a container. Things like this can potentially lead to the accident of a container vessel.

If the chief officer and the other crew do not understand the IMDG Code, it will impact to the second point of incorrect placement of DG Container. As explained in the IMDG Code (2014), there is a category of congestion and segregation for all types of dangerous goods containers. It is for the creation of salvation in the case of shipping and carrying cargo. Things that can cause accidents due to human factor and also related to the ship system is the installation of a less correct lashing system. The lashing system is an equipment that serves as a safety container, especially on the deck. If the installation of the lashing system is not correct, it will cause potential loss of cargo if the ship is unstable.

In addition to the installation of a less correct lashing system, re-checking lashing system becomes an important thing. For example, in the case of Annabella Ship, there are no lashing bars installed on the load, causing seven container units to fall into the ocean. This reflects the lack of checking of all lashing systems installed on the container load. Manual cargo is a guideline for securing the load carried by ship. This Guideline shall be owned by every ship, especially container vessel. Lack of understanding of manual cargo can lead to potential accidents (especially about container load) for not following the rules outlined in the guidelines. Some cases related to cargo securing manual include cases of ship accidents Pacific Adventurer, Dutch Navigator ship, ship P \& O Nedlloyd Genoa, Annabella ships and ships CMV Yorkshire. All types of container load carried by ship must be checked and inspected. The important thing in checking is that the container must be in good condition and ISO standard. If the container is not inspected first, it will cause potential damage to the container because it is not fit to fit. Things like this (especially if the containers are on the bottom tier) will cause the collapse of the heap in one container tier. One example of accidents due to lack of container checks is the case of Dutch Navigator shipwreck. 


\subsection{Management analysis}

Several management factors that may affect the crash of container vessels due to cargo on deck are container conditions that are not compliant with ISO standards, incorrect stowage plan placement, less qualified crew recruitment, shipping does not provide IMDG Code book, and packaging and placement of DG Container do not comply with IMDG Code.

Containers used as a cargo packing is of course under the responsibility of the container owner or the shipping party. Used containers must conform to ISO standards and in good condition. If the container is not in good condition, it will cause a potential accident on the load. Examples of accidents due to bad container conditions include the case of an accident ship Annabella and Dutch Navigator ship.

Stowage plans must comply with the principles and conditions of loading including container size, container type, container destination, and container weight requirements. If the planned stowage plan does not meet this aspect, it will affect the stability of the ship and the load. Examples of accidents related to the stowage plan are the case of the Annabella ship accident and the Dutch Navigator ship.

Recruitment of crew is done by the shipping party. This recruitment is quite important since the chosen people will be in charge of carrying and maintaining the shipping vessel on sailing. In addition to ships, cargo must be maintained by these people. If the crew has a complete certificate, but it is less than qualified, it will endanger the ship and the cargo. One example is a Chief Officer of Indonesian - flagged container vessels who do not understand the IMDG Code. This reflects that the ship's crew recruitment system should be further improved.

\section{Conclusions}

Based on the results of the analyses it could is concluded that the main causes of accident accrued to containers stacked on the deck of the ship are: the ship's systems, the environmental aspect, human factor aspect, and management aspect. The sources of these causes category identified through fishbone diagram analysis are used to find the solution for preventing them from occurring.

The authors would like to express their appreciations to PITTA project initiated by Directorate of Research and Community Engagement Universitas Indonesia, with contract No: 842/UN2.R3.1/HKP.05.00/2017 for funding the project.

\section{References}

1. I. Kurnia, I. Martinelli. Mimbar Hukum 28,1:123-137(2016). [in Bahasa Indonesia]. https://journal.ugm.ac.id/jmh/article/view/15860

2. C. Angga, R. Munir. Jurnal Sarjana Institut Teknologi Bandung bidang Teknik Elektro dan Informatika, 1,3:1-7(2012). [in Bahasa Indonesia] https://docplayer.info/30884172-Pengembangan-algoritma-greedy-untukoptimalisasi-penataan-peti-kemas-pada-kapal-pengangkut.html

3. UNCTAD. Review of maritime transport 2016. New York: United Nation Publication (2016). p. 31, 32. https://unctad.org/en/PublicationsLibrary/rmt2016 en.pdf

4. EMSA. Annual overview of marine cassualties and incidents 2017. [Online] from http://www.emsa.europa.eu/fc-default-view/tagged/84-accident-investigation.html (2017) [Acessed on March 04, 2018]. 
5. A.J. Scarvada, T. Bouzdine, S.M. Goldstein, J.M. Hays, A.V. Hill. A review of the causal mapping practice and research literature. Second World Conference on POM and 15th Annual POM Conference, (Cancun, Mexico, April 30 - May 3, 2004). p. 1-21(2004).

https://www.pomsmeetings.org/ConfProceedings/002/POMS_CD/Browse\%20Thi s\%20CD/PAPERS/002-0256.pdf

6. ASTB. Marine investigations and reports, [Online] from https://www.atsb.gov.au/publications/safety-investigation-reports/?mode=Marine (2017). [Acessed on March 04, 2018].

7. MAIB. Marine accident investigation branch reports. [Online] from https://www.gov.uk/maib-reports (2017). [Acessed on March 04, 2018].

8. Bundesstelle für Seeunfalluntersuchung. Annual report 2014. [Online] from https://www.bsubund.de/SharedDocs/pdf/EN/Annual_Statistics/annual_statistics_2014.pdf (2015). p. 32-33. [Acessed on March 04, 2018].

9. Transportation safety board of Canada. Marine transportation safety investigations and reports. [Online] from http://www.tsb.gc.ca/eng/rapports-reports/marine/ (2016). [Acessed on March 04, 2018].

10. A. Brandsæter, P. Hoffmann. Marine shipping quantitative risk analysis. [Technical Data Report]. Oslo, Norway: Det Norske Veritas (2010). p. 40 - 91. https://www.ceaa.gc.ca/050/documents_staticpost/cearref_21799/2559/marine_shi pping.pdf

11. UK P\&I Club. Lashing on containers on deck. [Online] from https://www.ukpandi.com/knowledge-publications/article/lashing-of-containerson-deck-1062/ (2006). [Acessed on May 04, 2017]. 